\title{
RECOGNISING MULTI-TEXTUALISM: RETHINKING NEW ZEALAND'S LEGAL HISTORY
}

\author{
R P Boast*
}

In this article the author discusses various written agreements that the New Zealand government has entered into with Māori since the signing of the Treaty of Waitangi in 1840. It is argued that the legal history of New Zealand is more "multi-textual", and more like Canada, the United States, and Argentina than is often thought. It is argued also that the process of agreement-making has been a continuously evolving one and at the present day is more important than ever. The article distinguishes between various types of Crown-Māori agreements and explores which of them are more Treaty-like than others.

In reality, relations with indigenous nations were not unidirectional, but bi-directional - Abelardo Levaggi. ${ }^{1}$

\section{INTRODUCTION}

\section{A Preliminary Considerations}

This article considers the case for reinterpreting New Zealand legal history based on a reconsideration of constitutional arrangements entered into between the Crown in right of New Zealand and Māori after the Treaty of Waitangi in 1840. Historians have long been aware that representatives of a number of important iwi (tribes) and hapu (sub-tribes) did not sign the Treaty of

* Barrister; Associate Professor of Law, Victoria University of Wellington. The author is acting or has acted for a number of claimant groups in the Central North Island, Urewera, National Park and Whanganui Waitangi Tribunal regional inquiries. This article is written solely for the purposes of academic discussion and of course makes no claim to reflect any kind of agreed position on behalf of any group currently in hearings. All archival references in this article are to Archives New Zealand, Wellington, unless otherwise stated.

1 Abelardo Levaggi Paz en la Frontera: Historia de las Relaciones Diplomáticas con las Comunidades Indigenas en la Argentina (Siglos XVI-XIX) (Universidad del Museo Social Argentino, Buenos Aires, 2000) (author's translation) ("Las relaciones con las naciones indígenas, en realidad, no fueron unidireccionales sino bidireccionales") 27. 
Waitangi. Of these, some have entered into a commitment to the Treaty subsequently. Other groups did not sign it and have not recognised it at any time. Some groups, however, entered into other kinds of agreements with the Crown later in the country's history. It is these other, later, agreements that will form the main subject of this article. Yet other groups signed both the Treaty of Waitangi and other pacts or arrangements. This complexity is an awkward historical reality that New Zealand constitutional discourse has simply ignored. The Treaty of Waitangi is said to be our founding document, an "always speaking" touchstone of the relationship between the Crown and Māori. In pursuing claims before the Waitangi Tribunal or in settling claims against the Crown, whether the group seeking redress ever, as a matter of historical reality, actually signed the Treaty is not perceived as relevant or even interesting, a general assumption that is reflected in the Waitangi Tribunal's statutory jurisdiction. ${ }^{2}$

And yet, on reflection, this is a little curious. If the Treaty of Waitangi is the foundation for the Crown's sovereignty, what is the position with regard to iwi who did not adhere to the Treaty? In fact, as a matter of law it is irrelevant whether any particular group acceded to the Treaty of Waitangi or not. It cannot be claimed as any kind of legal or constitutional reality that the Urewera region, where the tangata whenua (the Tuhoe) people were and still are non-signatories to the Treaty of Waitangi, is for that reason as a matter of law outside the sovereignty of the Crown (admittedly some Tuhoe might think differently). It has never been a characteristic of New Zealand political and legal discourse that the Crown's sovereignty rests on different foundations from region to region. The events of the founding year of 1840 are all-important, but the Treaty itself, a pre-condition perhaps of the Crown's assumption of sovereignty over New Zealand, is quite clearly not the legal foundation for that sovereignty.

Unravelling these conundrums today may well be impossible, and indeed undesirable. In terms of strictly legal outcomes such questions are resolved by the convenient device of justiciability. In the Seas and Submerged Lands case, a decision of the High Court of Australia, Gibbs J said that "the acquisition of territory by a sovereign state for the first time is an act of state which cannot be challenged, controlled or interfered with by the Courts of that state." ${ }^{3}$ In Brennan J's words in Mabo $v$ Queensland (No 2): ${ }^{4}$

2 See Treaty of Waitangi Act 1975, s 6. This allows "any Māori" to submit a claim that he or she or "any group of Māoris of which he or she is a member" is "prejudicially affected" by any Crown act, ordinance, Act, regulations, statutory instrument, policy or practice that was or is "inconsistent with the principles of the Treaty of Waitangi". If such a claim is "well-founded" the Tribunal may make recommendations to the Crown. By section 5(2) of the Act the Tribunal is directed to "have regard" to the Māori and English texts of the Treaty of Waitangi as set out in the First Schedule to the Act.

3 State of New South Wales v Commonwealth of Australia (1975) 135 CLR 337, 388 Gibbs J.

4 Mabo v Queensland (No 2) (1992) 175 CLR 1, 31 Brennan J. 
[The] principle, stated by Gibbs J in the Seas and Submerged Lands case, precludes any contest between the executive and the judicial branches of government as to whether a territory is or is not within the Crown's Dominions. The Murray Islands were annexed by an exercise of the prerogative evidenced by the Letters Patent; a mode of acquisition recognised by the common law as a valid means of acquiring sovereignty over foreign territory. The recognition is accorded simply on the footing that such a prerogative is an act of State the validity of which is not justiciable in the municipal Courts.

The Courts cannot sit in judgment on whether the Crown has sovereignty over New Zealand as a whole, or particular pieces of it. In New Zealand the matter is settled by statute. As shown by the decision in Berkett $v$ Tauranga District Court, ${ }^{5}$ the practice of the Courts has been to regard the provisions of the New Zealand Boundaries Act 1863 (UK) as authoritative.

In this article I will consider one aspect of this complexity, the status - or non-status, more accurately - of arrangements entered into between the Crown and Māori after 1840. These agreements certainly do live on in New Zealand public law and are regarded as very significant by descendants of signatories on the Māori side. Nevertheless few legal commentators are aware of them. At the very least, a consideration of their status and effect seems both interesting and long overdue. Mostly this article will focus on clarifying the different types of Crown-Māori agreements, propose a method of ranking them in a hierarchy, and raise some questions concerning their status and effect. The main aspiration of this article is to stimulate further academic discussion of these agreements and to create a wider awareness of their existence and significance. ${ }^{6}$ As will be seen, the process of devising agreements between the Crown and Māori and giving effect to them by statute

5 Berkett v Tauranga District Court [1992] 3 NZLR 206, 211 (HC) Fisher J. The New Zealand Boundaries Act 1863 is a statute of the United Kingdom, not the New Zealand, Parliament. The existence of this Act precluded the necessity for further inquiry, but the High Court appears to accept in Berkett $v$ Tauranga District Court that the Crown's proclamations of sovereignty in 1840 are unchallengeable in any event, despite the "questionable nature of some of the assumptions purportedly justifying the proclamations at the time" (at 213). See also the dictum of Richardson J in New Zealand Māori Council v Attorney-General [1987] 1 NZLR 641, 690 (CA): "It now seems widely accepted as a matter of colonial law and international law that those proclamations approved by the Crown and the gazetting of the acquisition by the Crown in the London Gazette on 2 October 1840 authoritatively established Crown sovereignty over New Zealand".

6 There have been only three recent published discussions of the subject in the academic literature that the author is aware of, these being: my own brief analysis in the first and second editions of P Spiller, J Finn and R Boast A New Zealand Legal History (1 ed, Brookers, Wellington, 1993) 133-134 (2 ed, Brookers, Wellington, 2001) 48-49; James Belich Making Peoples: A History of the New Zealanders from Polynesian Settlement to the End of the Nineteenth Century (Allen Lane, Auckland, 1996) 202 [Making Peoples]; and Vincent O'Malley "Treaty-making in Early Colonial New Zealand" [1999] 33 NZJH 137 ["Treaty-making"]. O'Malley's essay is reprinted in Judith Binney (ed) The Shaping of History (Bridget Williams Books, Wellington, 2001) 129-145. This study develops certain ideas in two unpublished reports that O'Malley prepared for the Waitangi Tribunal's Mohaka ki Ahuriri (Wai 201) Inquiry: see his The Treaty of Ahuriri: Supplementary Evidence of Vincent O'Malley in Relation to the Ahuriri Purchase of 1851 (Wai 201, Doc O2, 1997) and 'Where is the Doctor for the Māoris?': Te Tiriti o Te Ahuriri and the Provision of Health Services to Central Hawke's Bay Māori, 1851-1940 (Wai 201, Doc U12, 1999). 
has not come to an end. Quite the contrary: more major negotiations are going on at the present time than at any time in the country's history. Although the current round of negotiations and settlements is not the main focus of this article, it is interesting to consider the extent to which contemporary processes in many ways mirror how the government and Māori groups have arranged matters in the past.

The question of the status, effect, and significance of earlier "treaties", other than the Treaty of Waitangi, between the Crown and Māori has become of some practical importance in a number of recent major regional inquiries of the Waitangi Tribunal conducted under the Treaty of Waitangi Act 1975. Such questions have arisen in the Urewera and Central North Island regional inquiries, which have now been heard but not yet reported on by the Waitangi Tribunal; in the National Park inquiry, currently in hearings; and are certain to arise in the King Country regional inquiry, the hearing of which is still some time away. These inquiries have raised, successively, questions relating to the Urewera negotiations and agreement of 1895, the "Fenton Agreement" with Te Arawa of 1880 and the "Aotea (King Country) Agreement" of 1884. These are the most important of the post-Treaty of Waitangi Crown-Māori agreements, but there were many others. In a recent Waitangi Tribunal report, for example, the Tribunal had to consider the argument that there was a kind of special relationship between the Crown and Ngāti Whātua arising from an "alliance" created at the time of the first settlement of Auckland in $1840 .^{7}$

\section{B Internal Treaties and National Sovereignty}

From a legally formalist standpoint, "treaties" are pacts concluded between parties who have legal personality in international law, and from that perspective there cannot be any such thing as a "treaty" between, say, the Crown and the tribes of the independent King Country, any more than the Crown and Ngai Tahu can draw up a "treaty" at the present day (although in some ways they have in fact done exactly that). The special sense in which "treaties" between Indian nations and the United States are recognised in federal Indian law has no counterpart in New Zealand either, as there is no body of doctrines here that is equivalent to the well-established principles in the United States governing the sovereign status of indigenous peoples. In fact, Māori iwi have no constitutional or even corporate existence in New Zealand law at all, although there are many forms of Māori legal entities. These are not, however, entities that ever entered into any kind of treaty-like relationship with the government; rather, they are themselves creatures of statute. ${ }^{8}$

7 Waitangi Tribunal Kaipara Report: Wai 674 (Legislation Direct, Wellington, 2006) 151-158 [Kaipara].

8 The issue of Māori governance entities is vitally important at the present time, given the rapid evolution of fisheries and historic claims settlements since 1989 and the need to devise entities that are capable of receiving, holding and managing assets and monies transferred by way of settlement. The Law Commission has released a major report on this problem: See Law Commission/Te Aka Matua o Te Ture Waka Umanga: A Proposed Law for Māori Governance Entities (NZLC R92, Wellington, 2006). The Commission has 
The position is, in this sense, simple: there are no internal "treaties" between the Crown and Māori within New Zealand as a matter of law. If the legal reality, this is not, however, the historical reality or any kind of reflection of the actual practice of the colonial State - or, perhaps, the contemporary State. The situation in New Zealand has some similarities with Argentina, as analysed by the Argentine legal historian Abelardo Levaggi. In his study Paz en la Frontera (Peace on the Frontier), ${ }^{9}$ Levaggi has collected together and analyzed hundreds of agreements entered into between the Spanish Crown and, subsequently, by various post-independence governments of what today is Argentina, with the Indians of the Chaco region of the Pampas and of Patagonia. Given, he notes, the "practical impossibility ... of enforcing the submission of the free [Indian] communities to the general law", both the Spanish Crown and the various governments of the Republic of Argentina, "without renouncing their ultimate objective of achieving a complete domination of the [national] territory", had to have recourse to a kind of temporary ad hoc law, loosely based on international law rather than the ordinary domestic law of obligations, that relied on the internal treaty as its "fundamental instrument". ${ }^{10}$ It is the post-independence republican period in Argentina which most closely parallels the experience of New Zealand, given the contradiction between the government's refusal to accept any kind of sovereignty residing in the various Indian tribes and the practical necessity of concluding treaties with them: ${ }^{11}$

The conduct of the State of Argentina, in contrast with that of the Spanish Crown, was certainly contradictory. On the one hand it did not recognise that the indigenous groups were legal entities of a national character (that is, they were not sovereign states), while, on the other, it concluded peace treaties with them, which carried with them such recognition implicitly.

The same can be said of at least some of the Crown-Māori agreements discussed in this article. The fact is that there is a disjuncture between legal theory and actual State practice, both in New Zealand and in Argentina.

The position in Argentina and New Zealand can be contrasted with the status of treaties with indigenous groups in the United States. There are a large number of these texts, which are of varying degrees of relevance in United States law today. Some were entered into by former colonial

proposed that a new type of Māori governance body, a waka umanga (meaning "a vehicle for community affairs") be set up by statute.

$9 \quad$ Levaggi, above n 1.

10 Levaggi, above n 1, 19 (author's translation). For the context of frontier treaty-making in the later history of the Spanish colonial empire see generally David Weber Bárbaros: Spaniards and their Savages in the Age of Enlightenment (Yale University Press, New Haven and London, 2005).

11 Levaggi, above n 1, 563 (author's translation). ("La conducto del Estado argentino, a diferencia de la Corona española, fue, ciertamente, contradictoria. Por un lado, no reconocío que los indígenas formasen comunidades jurídicas con categoria de nación (no Estados soberanos), y, por el otro, había firmado con ellos tratados de paz, que llevaban implícito ese reconocimiento.") 
powers (Britain, Spain, France, the Netherlands) with the various tribes, and others concluded with the Federal Government between 1778 to 1868 (there are over 350 treaties in the latter category alone). ${ }^{12}$ In the United States, these texts operate within a legal framework arising from the constitutional structure of the United States as a federal system. Equally important is the "Marshall trilogy": the three key decisions of the United States Supreme Court in Johnson v McIntosh, ${ }^{13}$ Cherokee Nation v Georgia ${ }^{14}$ and Worcester v Georgia. ${ }^{15}$ In Cherokee Nation v Georgia, Marshall CJ famously characterised "those tribes which reside within the acknowledged boundaries of the United States" as "domestic dependent nations". ${ }^{16}$ Concluding "treaties" with Indian nations even within those "acknowledged boundaries" is not legally problematic as far as American lawyers are concerned. ${ }^{17}$ On the other hand, it needs to be recognised that the treaties negotiated in the United States were based on marked inequality of bargaining power: "The results of treaty negotiations were almost always unsatisfactory to the Indians". ${ }^{18}$

The legal position in New Zealand has much more in common with Argentina than it does with the United States. According to Levaggi: ${ }^{19}$

In contrast with the United States, where treaties with the tribes have "the same status as treaties with foreign states", according to legal doctrine repeatedly confirmed by the Federal Courts, and where, with some exceptions, it is not contested that the Constitution accords to these treaties the status of supreme law, or, where, in other words, legal pluralism is well-recognised, in the Republic of Argentina, arising

12 The legal and historical literature on treaties between governments and indigenous peoples in North America is colossal. The best general historical overview is Wilcomb E Washburn (ed) Handbook of North American Indians: Volume 4: History of Indian-White Relations (Smithsonian Institution, Washington DC, 1988), especially the chapters by Dorothy Jones (at 185-194), Robert Kvasnicka (at 195-201) and Robert Surtees (at 202-210) on British, United States, and Canadian Indian treaties. For a basic collection of key cases and articles see David H Getches, Charles F Wilkinson and Robert A Williams Jr Cases and Materials on Federal Indian Law (West Group, St Paul, Minnesota, 1998) especially 73-139. A useful collection of essays dealing with a number of common law jurisdictions, focusing principally on recent agreements, is Marcia Langton, Maureen Tehan, Lisa Palmer and Kathryn Shainn (eds) Honour Among Nations? Treaties and Agreements with Indigenous People (Melbourne University Press, Melbourne, 2004).

13 Johnson v McIntosh (1823) 21 US 543.

14 Cherokee Nation v Georgia (1831) 30 US 1.

15 Worcester $v$ Georgia (1832) 31 US 515.

16 Cherokee Nation v Georgia, above n 14, 16 Marshall CJ.

17 The leading United States decision, apart from the Johnson trilogy, is United States v Winans (1905) 198 US 371. On the effect of treaties on fishing rights see especially United States v State of Washington (1974) 384 F Supp 312.

18 Charles F Wilkinson and John M Volkman "Judicial Review of Indian Treaty Abrogation: 'As Long as Water Flows, or Grass Grows upon the Earth' - How Long a Time is That?" (1975) 63 Ca L Rev 601, 610.

19 Levaggi, above n 1, 561 (author's translation). 
out of the search for a national identity that is unified, homogenous, and hostile to any suggestion of legal pluralism, treaties [with indigenous groups] were at first denied the same status as those in North America, and then were subsequently scorned, nullified, were lost and forgotten, as if they had never existed in the first place.

The situation of, say, the Fenton Agreement or the Tuhoe Agreement is the same. It is as if they have been erased from the nation's legal history. And the explanation in both Argentina and New Zealand is a hostility, at least until recently, to any suggestion of legal and jurisdictional pluralism within the framework of a highly positivist legal culture. In New Zealand even the Treaty of Waitangi itself has won, at best, only grudging acceptance as a constitutional text on the part of courts and most commentators on constitutional law, to say nothing of other agreements, which seemingly have the status of historical curiosities.

And yet, as Levaggi goes on to argue, such a stance does not accord with historical reality. Writers in Argentina who stress the fundamental constitutional differences between Argentina and the United States, as an explanation of the different status of indigenous treaties in both jurisdictions, overlook the fact that to a large extent in both North and South America treaty-making with the frontier tribes was an established practice of the Spanish Crown (as well of the British Crown in North America). In both countries, as well, the practice was inherited by the independent republican regimes once the respective colonial powers had been evicted from the scene. In the United States, Argentina and New Zealand alike, relations between governments and the indigenous tribes were characterised by peace and by agreements as much as they were characterised by war and conflict. The difficulty now lies in finding some kind of conceptual legal language to characterise such agreements and, perhaps, to give them status. In both countries, while formally there is no conception of any kind of plural sovereignty, as a matter of historical practice treaty-like agreements between the government and indigenous tribes were an established State practice.

\section{A MULTI-TEXTUAL LEGAL HISTORY}

\section{A Introduction}

The general view is that in terms of its constitutional arrangements between the Crown and Māori, New Zealand's legal history is unitextual: there is just one agreement, or at least just one that matters, this being the Treaty of Waitangi itself. Thus New Zealand can be contrasted with multitextual jurisdictions such as Canada, the United States, or Argentina, where there were numerous negotiations and, as a consequence, "treaties" between the colonial authorities and the indigenous population. A moment's reflection, however, will immediately destroy this illusion, at least as a matter of the historical record. The expansion of the colonial frontier in both the North and the South Island was accompanied by a myriad of written agreements with Māori. This is well-known to historians. In fact the colonial history of New Zealand is also multi-textual. The question is not the existence of other texts and agreements apart from the Treaty of Waitangi, but rather how we 
choose to describe them, or the labels we wish to attach to them. What is a "treaty" in one jurisdiction becomes a "pre-emptive purchase deed" in another, but the content is no different.

\section{B Deeds of Cession}

The most familiar type of agreement between Māori and the colonial State are land cessions in the period before the establishment of the Native Land Court in 1862. Before that time about $60 \%$ of the country, including the entirety of the South Island as well as large tracts of the North, passed into the effective control of the Crown as a consequence of what are sometimes known as preemptive land deeds or sales, but which can much more appropriately be thought of as local or regional land cessions. There were hundreds of these agreements. These texts have been much studied in a number of well-known historical works and have also been scrutinised on a number of occasions by the Waitangi Tribunal. ${ }^{20}$

It might be thought that there are substantial differences between a land cession and a "treaty", but this is not so. Most of the texts which have the status of "treaties" in North America in fact often were land cessions, no different from their New Zealand counterparts. Moreover at least in some, or perhaps many cases in New Zealand and North America alike, the agreements amounted to rather more than mere cessions. Indeed the New Zealand cessions are virtually always written in the Māori and English languages, while most North America land treaties are only in English. ${ }^{21}$ This is largely because many North American indigenous languages had not evolved into written languages in the $19^{\text {th }}$ century, whereas Māori had (in fact there is a very substantial body of written Māori, published and unpublished, produced in $19^{\text {th }}$ century New Zealand). Given that the texts are written in Māori, and were usually the product of negotiations between Māori chiefs and Crown officials who could speak, and indeed write, Māori fluently, the $19^{\text {th }}$ century New Zealand cessions might even be said to have a better claim to be regarded as "treaties" than their counterparts in the American and Canadian West drawn up at the same time.

20 Probably the best-known of the pre-emptive deeds are the Ngai Tahu deeds of 1844-1864, which were the primary focus of the Waitangi Tribunal's Ngai Tahu Report: Wai 27 (3 vols, Brooker and Friend Ltd, Wellington, 1991); on these deeds see also H E Evison Te Wai Pounamu: The Greenstone Island: A History of Southern Māori During the European Colonization of New Zealand (Aoraki Press, Christchurch, 1991); The Long Dispute: Mãori Land Rights and European Colonisation in Southern New Zealand (Canterbury University Press, Christchurch, 1997); and The Ngai Tahu Deeds: A Window on New Zealand History (Canterbury University Press, Christchurch, 2006) [Ngai Tahu Deeds]. The latter volume contains highquality colour reproductions of all of the Ngai Tahu deeds and the Wairau deed of 1847 concluded with three rangatira of Ngāti Toa, together with their associated sketch plans. For a more interpretive and analytical approach to the pre-emption era deeds see Angela Ballara "The Pursuit of Mana? A ReEvaluation of the Process of Land Evaluation by Māoris, 1840-1890" (1982) 91 Journal of the Polynesian Society 519; Ann Parsonson "The Challenge to Mana Māori" in G W Rice (ed) The Oxford History of New Zealand (2 ed, Oxford University Press, Auckland, 1992) 167.

21 See Wilkinson and Volkman, above n 18, 610-611; Jones $v$ Meehan (1899) 175 US 1, 11. 
In terms of legal analysis, the principal judicial statement is that of Prendergast CJ in Wi Parata $v$ Bishop of Wellington. ${ }^{22}$ The case was concerned with Crown grants, but Prendergast CJ seems to have regarded all "acts of the Crown in dealing with the aborigines for the cession of their title" as Acts of State, none of which could be "examinable in any court of the country". ${ }^{23}$ I have not discovered any case where the parties treated a land deed as a contract and sued on it in civil proceedings, either on the part of Māori for breach or, for that matter, by the Crown (for specific performance, for example). Further legal-historical research may perhaps turn up some examples. There have been some moves recently to bring an action in the contemporary Courts based on breaches of Crown-Māori agreements entered into in the Wellington region in the 1840 s, but nothing has been determined and the difficulties confronting such a claim are formidable, although perhaps not insuperable.

With the establishment of the Native Land Court the history of land alienation on the New Zealand colonial frontiers moved into a new phase. Once Māori had obtained a certificate of title and a Crown grant under the Native Lands Acts they became freeholders of such land, and were free to alienate it on an open market to either private-sector purchasers or the Crown. The Fox-Vogel regime that took office in 1869 pursued a reinvigorated programme of land purchasing as part of a programme of accelerated economic development of the North Island bush frontier. The Native Lands Acts converted Māori land into freeholds held under tenancy in common, which meant that it was possible for purchases to become individualised: rather than conduct public negotiations and draw up texts, purchasers could simply approach individual owners and purchase their undivided shares, subsequently proceeding to either gain title to the entirety of the block, or to partition it between sellers' and non-sellers' portions in the Native Land Court. Government land purchase officers became highly adept in these techniques, leading to a particularly economically and socially debilitating land purchasing system in the period from 1870-1920. During this time most of the remaining Māori lands in the North Island passed into the hands of the Crown and private buyers.

The ending of pre-emptive purchasing by deed did not, however, mean that negotiations and agreements between Māori and the Crown came to an end: far from it. In fact post-1865 agreements have an even better claim to be regarded as "treaties" than the land cession texts of the 1840-1862 period. After 1865 there were fewer agreements but arguably their significance is even greater.

\section{Confiscation Agreements}

These later agreements, the main focus of this article, belonged to two major categories. The first were confiscation agreements. In 1863 the government decided to embark on the course of punishing "rebel" Māori by confiscating their lands and then regranting them either to "loyal" Māori

22 Wi Parata $v$ Bishop of Wellington (1877) 3 NZ Jur (NS) SC 72 [Wi Parata].

23 Wi Parata, above n 22, 79 Prendergast CJ. 
or to settlers, the latter often being pensioned-off soldiers. ${ }^{24}$ This highly coercive system of confiscation, regrant and military settlement was similar to the policies of the English Government in $17^{\text {th }}$ century Ireland - a dubious precedent as some critics of the programme in New Zealand were not slow to point out. ${ }^{25}$ As in Ireland, confiscation in New Zealand was in part a compulsory movement of peoples: Māori were were to be moved out of certain areas, and Pākehā settlers moved in. In reality confiscation turned out to be a confused and messy affair - as indeed had been the case in Ireland - and in a number of instances the Crown entered into agreements with Māori as a way out of the impasse. These agreements were then translated into legislation.

An example is Mohaka-Waikare confiscation in Hawke's Bay, ${ }^{26}$ recently considered at some length by the Waitangi Tribunal in a regional inquiry report released in $2004 .{ }^{27}$ The original Mohaka-Waikare confiscation was carried out pursuant to the New Zealand Settlements Act 1863, and it is thus akin to the Waikato, Taranaki and Tauranga confiscations. It was, as the Waitangi Tribunal has noted, the last in the sequence of New Zealand Settlements Act confiscations. ${ }^{28}$ At the outset of its detailed review of the confiscation process in chapter 8 of its Mohaka ki Ahuriri report, the Tribunal stresses the "capricious" and politicised nature of the confiscation process, noting the variety in practice and the importance of political shifts in Wellington: ${ }^{29}$

24 The principal statutory vehicle for confiscation in New Zealand was the New Zealand Settlements Act 1863. This led to a complex sequence of amending and supplementary enactments, these being the New Zealand Settlements Act Amendment Act 1864, the New Zealand Settlements Amendment and Continuance Act 1865, the New Zealand Settlements Amendment Act 1866, the Friendly Natives' Contracts Enforcement Act 1867 and the Confiscated Lands Act 1867. There was also a great deal of special legislation enacted to deal with local problems, for instance the Tauranga District Lands Act 1867 (on which see Faulkner v Tauranga District Council [1996] 1 NZLR 357 (HC)). On the development of the confiscation programme see B J Dalton War and Politics in New Zealand 1855-1870 (Sydney University Press, Sydney, 1967) especially 211-219.

25 See Sir William Martin "Observations on the Proposal to take Native Lands under an Act of the Assembly" [1864] AJHR E-2, 7-8 (Martin was the former Chief Justice of New Zealand). On confiscation in early modern Ireland see Nicolas Canny Making Ireland British 1580-1650 (Oxford University Press, Oxford, 2001); T W Moody, F X Martin and F J Byrne (eds) A New History of Ireland: III: Early Modern Ireland (Clarendon Press, Oxford, 1976) especially chs VII and IX (by Aidan Clarke) and XIV (by P J Corish); J G Simms The Williamite Confiscations in Ireland 1690-1703 (London, 1956).

26 On this confiscation and its confused aftermath see Dean Cowie Hawke's Bay (Waitangi Tribunal Rangahaua Whanui Report, 1996) 101-176; R P Boast The Mohaka-Waikare Confiscation: Consolidated Report (Wai 201, Doc J28 and J29, 1995); Richard Moorsom Raupatu, Restoration, and Ancestral Rights: The Title to Tarawera, Tataraakina and Te Haroto: Main Report (Wai 201, Doc R3, 1998).

27 Waitangi Tribunal The Mohaka ki Ahuriri Report: Wai 201 (2 vols, Legislation Direct, Wellington, 2004) [Mohaka ki Ahuriri] ("[from] Mohaka to Ahuriri", these being places in northern Hawke's Bay).

28 Mohaka ki Ahuriri, above n 27, 225.

29 Mohaka ki Ahuriri, above n 27, 221. 
Though the Mohaka-Waikare confiscation might seem a logical extension of the [confiscation] policy, applied in response to the spread of 'rebellion' into Hawke's Bay, it appears to us to have been an anomaly. Indeed, as the earlier raupatu reports have pointed out, there was no consistent application of the confiscation policy. Rather, it was applied capriciously in response to changing circumstances, and as a consequence of frequent changes in ministries.

The Tribunal went on to describe the many variants in practice: ${ }^{30}$

In the eastern Bay of Plenty, for instance, the Outlying Districts Police Act 1865 was passed to provide for the confiscation of the land of those suspected of killing Volkner and Fulloon, but it was not used for that purpose and the Government fell back on the New Zealand Settlements Act as a basis for that confiscation. Then, in 1866, the East Coast Land Titles Investigation Act was passed to provide for the confiscation of land in Wairoa and Poverty Bay. That Act used the Native Land Court rather than the Compensation Court to investigate the titles of non-rebels. But the Act was not applied further south, and the Mohaka-Waikare confiscation, like the eastern Bay of Plenty confiscation, was based on the New Zealand Settlements Act. Having used that Act, however, the Government did not use the Compensation Court to distinguish the land of 'rebels' from that of 'loyalists': instead, it relied on agreements between Crown officials and Māori claimants, and these were subsequently blessed by validating legislation.

This last statement captures admirably the diversity and regional complexity of the confiscation process. It also makes plain a key feature of the Mohaka-Waikare confiscation, this being the perhaps surprising extent to which this confiscation revolved in the end around negotiated agreements between Māori groups and the government - the "government" being not so much the central government in Wellington as the Hawke's Bay provincial government located very close to the action at Napier. ${ }^{31}$ Confiscated under the New Zealand Settlements Act in 1866, most of the confiscated blocks were returned by means of an agreement drawn up between pro-government Hawke's Bay chiefs, and officials of the provincial government at Napier in 1870. There was an earlier agreement in 1868, but this was never finalised after Te Kooti's attack on the Ngāti Kahungunu settlement at Mohaka in 1869 caused the attention of Māori and Pākehā in the province to be focused elsewhere. The 1870 agreement, negotiated on the government's behalf by a local magistrate, was then given effect to by the Mohaka and Waikare Districts Act 1870. However the blocks, albeit returned, were not necessarily returned to their former owners. The most valuable block, Kaiwaka, was handed over to one individual, the chief Tareha, whose rights to the block under customary law were tenuous at best, although he was certainly a great and esteemed chief and

30 Mohaka ki Ahuriri, above n 27, 221-222.

31 The political and legal history of the provincial governments before 1876 is another topic that could do with some attention from legal historians. 
related to most people in the area. It was a contentious step which ultimately resulted in major litigation and a decision of the Privy Council. ${ }^{32}$

Another, quite different, example is that of the intricate history of the Waiau, Tukurangi, Ruakituri and Taramarama blocks, located in the inland Wairoa area. In 1875-76 all four blocks were acquired by the Crown by three distinct cash payments: one to Ngāti Kahungunu owners as identified by the Land Court; another to Tuhoe and Ngāti Ruapani (who received a smaller payment and some reserves); and a third to those of Ngāti Kahungunu who had demonstrated their loyalty to the Crown but who had no recorded customary interests in the blocks. These purchases, however, took place after a long process of negotiation stretching back over the preceding ten years. The Crown had threatened to confiscate the area, but had not actually done so, and in 1870 entered into an agreement with local Māori at Te Hatepe in 1867 by which "loyal" Māori were allocated a major role in confiscating the land of other groups. The purchases which took place in 1875-76 were not technically confiscation, but given the prior history of actual and implied threat they were anything but purchases at arm's length. Although the statutes were not actually used, "the legislation was used as a 'big stick' to induce Māori to cede (sell) blocks of land in return for a commitment not to use the confiscation framework". ${ }^{33}$ This is another example of an agreement arising within the general framework of confiscation.

\section{Regional Pre-emptive Agreements}

The colonial State did not acquire actual political control over the whole of the country with Hobson's proclamation of sovereignty in May 1840. With the end of the New Zealand wars and the military defeat of the Māori King movement by the British army, the Crown's practical sovereignty over the North Island interior was greatly extended, and now included the Waikato, but it was still not complete. Māori maintained independent polities in a number of areas. One of these enclaves, that around Parihaka in central Taranaki, was suppressed forcibly in 1881 when, mounted theatrically on a white horse, the Native Minister in the Hall Government, John Bryce, led a force of 959 volunteers and 630 Armed Constabulary into Parihaka and brought its independence to an abrupt end. ${ }^{34}$ This is a famous event that has achieved a kind of iconographic position in New

32 Te Teira Te Paea v Te Roera Tareha [1902] AC 56 (PC). The case was concerned with whether Crown grants made pursuant to the Mohaka and Waikare Districts 1870 were fee-simple grants or were made in trust. The Privy Council found that the grants were fee-simple grants. This was one of only two occasions on which cases related to confiscated lands in New Zealand were considered by the Privy Council, the other being Kapua v Haimona [1913] AC 761 (PC).

33 Michael Belgrave and Grant Young The Urewera Inquiry District and Ngati Kahungunu: War, Confiscation and the 'Four Southern Blocks' (Report Commissioned by the Crown Forestry Rental Trust, Wai 894, Doc A131, 2003) 5.

34 The events at Parihaka are the subject of Dick Scott's classic book Ask That Mountain: The Story of Parihaka (Reed/Southern Cross Books, Auckland, 1975). See also Hazel Riseborough Days of Darkness: Taranaki 1878-1884 (Allen and Unwin/Historical Branch, Department of Internal Affairs, Wellington, 
Zealand history and in the mind of the public. ${ }^{35}$ However, the de facto independence of other regions was resolved differently: by agreement.

The agreements which perhaps have the best claim of all to be classed as "treaties" arose as the outcome of complex negotiations which ended, in succession, the autonomy of the three large remaining areas of Māori self-government (apart from Parihaka) after the closure of the New Zealand wars around 1872. The wars left at least three major regions more or less still under Māori control: the King Country, or the Rohe Potae; the Rotorua region; and the Ureweras. ${ }^{36}$ These areas were the domain, successively, of Ngāti Maniapoto, Ngāti Raukawa and some of the upper Wanganui groups; of Te Arawa; and, lastly, of the Tuhoe, Ngāti Whare, and related kin groups of the Urewera-Te Whaiti region. During the New Zealand wars Ngāti Maniapoto had fought against the Crown and afterwards gave refuge to King Tawhiao. Tuhoe had also fought the Crown and had allied themselves with Te Kooti, paying a very heavy price for this commitment. Te Arawa, however, had largely allied themselves with the government, but were no less determined to maintain their independence. A particular issue was the Native Land Court. The leaders of all three independent districts had exclusion of the Native Land Court from their respective regions as one of their primary goals, an aspiration which failed in the end in all three. ${ }^{37}$

1989). The Waitangi Tribunal has also reported on events at Parihaka and was predictably critical of the government's actions: see Waitangi Tribunal The Taranaki Report: Kaupapa Tuatahi (Government Printer, Wellington, 1996) 200-239; for critical analysis of the Waitangi Tribunal's analysis see Michael Belgrave Historical Frictions (Auckland University Press, Auckland, 2005) 217-283; and W H Oliver "The Future Behind Us: The Waitangi Tribunal's Retrospective Utopia" in Andrew Sharp and Paul McHugh (eds) Histories, Power and Loss (Bridget Williams Books, Wellington, 2001) 9-29.

35 See the superbly illustrated work by T M Hohaia, G O'Brien and L Strongman (eds) Parihaka: The Art of Passive Resistance (City Gallery and Victoria University Press, Wellington, 2001).

36 The incomplete or inconclusive outcome on the North Island frontier of the Crown's programme of military invasion and conquest has some interesting parallels in Latin America - in the case of the Maya of the southern parts of the Yucatan peninsula or with the Mapuche and other groups in the Araucanian region of Chile. These independent zones existing within the nominal sovereignty of the Spanish Crown have recently attracted the attention of a number of historians: see for example Pedro Bracamonte y Sosa and Miguel Angel Porrúa La Conquista Inconclusa de Yucatán (CIESAS, University of Quintana Roo, Mexico DF, 2001) (one could similarly speak of the "inconclusive conquest of the North Island"); Grant D Jones The Conquest of the Last Maya Kingdom (Stanford University Press, Stanford, 1998); David J Weber Bárbaros: Spaniards and Their Savages in the Age of Enlightenment, above n 10.

37 In the King Country, major Native Land Court investigations of title began in 1886 with the investigations of title to the Waimarino, Tauponuitia and King Country Blocks. It was a term of the Fenton Agreement of 1880 that the Native Land Court could sit at Rotorua, which led to the first major investigation of title, to Pukeroa-Oruawhata, in 1881. This was soon followed by a sequence of other major cases. In the Urewera region, the Urewera District Native Reserve Act 1896 did in fact establish a special commission to replace the Court (the Urewera Commission) but in 1909 the jurisdiction of the Court was restored to Te Urewera. 
During the 1870 s the colonial State acquiesced in the continuation of this situation and concentrated on settling other areas of the North Island forest frontier, such as the Wairarapa and the confiscated Taranaki and Waikato. ${ }^{38}$ Donald McLean, Native Minister in the Fox-Vogel Government, entered into peace agreements with the Kingitanga and with the Tuhoe people of Te Urewera in the years from 1869-1872 which essentially accepted continued autonomy, at least for the time being. In the period from 1880-1895 the independence of the three districts slowly came to an end as the result of complex negotiations, each resulting in an agreement which was then given legislative effect. It is these three agreements which live on at the present day, which are regarded as of great significance by the groups concerned, and which in all three cases involve groups who did not sign the Treaty of Waitangi in 1840. These are also the agreements which have been, or will be, of real significance in important Waitangi Tribunal regional inquiries. In at least one case, the government has been prepared to enter into negotiations and settlements based on one of the three agreements, indicating that it has a public law status of some sort.

The three agreements, which will be discussed in more detail below, have one key feature in common; all are in part regional restorations of Crown pre-emption. In each case, negotiations led to an agreement, given effect to in statute, one key aspect of which was to give to the Crown a monopoly right to purchase Māori land in the affected region and to disbar private buyers. For this reason I have referred to them as regional pre-emptive agreements. These agreements paved the way for the full nation-wide reimposition of Crown pre-emption in 1894.

\section{PARTICULAR REGIONAL PRE-EMPTIVE AGREEMENTS}

\section{A The Fenton Agreement and Te Arawa}

In 1880, on the instructions of William Rolleston, then Native Minister in the conservative Hall Government, former Chief Judge Fenton of the Native Land Court made an arduous journey from Hawke's Bay to Rotorua to hold a key meeting with the leaders of Ngāti Whakaue, which was (and still is) a significant iwi of the Te Arawa confederation of the Rotorua-Bay of Plenty district. Fenton's telegraphed instructions were in the vaguest of terms and he was given a remarkably free hand to do what he thought best: ${ }^{39}$

Mr Rolleston who is absent in Canterbury requested me [John Bryce] to reply to your telegraph of the $5^{\text {th }}$ instant re the Rotorua business [not on the file]. Both he and I would be very glad if you would return overland as you suggested and endeavour on what conditions the Māoris would be willing to dispose of enough land near Rotorua to remove the present difficulties and obviate future ones in respect to Hotel accommodation for visitors to the lake. Government would agree to almost anything which would be

38 On the settlement of the North Island frontier in the 1870 s see especially Rollo Arnold The Farthest Promised Land, English Villagers, New Zealand Immigrants of the 1870s (Price Milburn and Victoria University Press, Wellington, 1981).

39 Bryce to Fenton (date illegible - 10 November 1880?) (Archives New Zealand, Wellington, MA 13/79). 
effectual as township should however be formed to secure sanitary regulations being enforced. This might be secured either by sale or by lease. If they [illegible] the latter the lease should still be a long one. However you know what is required and Government will look forward to your report in the hope that you will be able to advise some course which will render the Lake Country more agreeable to visitors than it is at present.

Fenton took with him Wiremu Hikairo, an Assessor of the Native Land Court and "a landowner and a man of importance in the Rotorua country". ${ }^{40}$ Rotorua was then an area of autonomous Māori authority from which the Native Land Court was excluded, although it was at the same time the centre of a booming tourist industry for visitors to the "Hot Lakes" district, and the Pink and White Terraces at Rotomahana. ${ }^{41}$ Most of Te Arawa, including Ngāti Whakaue, had either actively supported the Crown during the New Zealand wars or had remained neutral, this largely arising out of traditional Māori political alignments. Te Arawa were traditional enemies of the Tainui people of the Waikato and Tauranga tribes, bastions of support for the Māori King.

At Rotorua Fenton met with the Komiti Nui (Great Committee) of Ngāti Whakue in their famous meeting house of Tamatekapua at the lakeside village of Ohinemutu. Fenton reported that he found at Ohinemutu "a regularly organised head body with Chairman, Secretary and officers". The Komiti Nui, said Fenton, was originally "constituted as a Land League for the prime object of preventing alienation to the Crown", but had come to have a number of other quasi-governmental functions. ${ }^{42}$ Māori chiefs of the region wanted to accelerate the economic growth of their region and to have schools established to educate their children. The government, for its part, wanted to regularise land tenure around Rotorua and to obtain better oversight and control of the unregulated tourist traffic in the area. The upshot of the discussions was a written agreement drafted by Fenton in the Māori language and afterwards formally endorsed by the Governor General, which has come to be known as the "Fenton Agreement". It was principally concerned with the arrangements for a new town to be laid out at Rotorua. Following a survey to be conducted by the Chief Surveyor, the Native Land Court was allowed to sit at Rotorua and to adjudicate on the block known as Te Pukeroa, or Pukeroa-Oruawhata (a valuable parcel which now accounts for virtually the whole of the modern city). ${ }^{43}$ The Māori village at Ohinemutu was to be left out of the survey and the Court

40 Fenton "Report" (18 December 18 1880) (Archives New Zealand, Wellington, MA 13/79).

41 There is a rich literature on the history of the Rotorua region in the later $19^{\text {th }}$ century. See Ngahuia Te Awekotuku The Sociocultural Impact of Tourism on the Te Arawa People of Rotorua (PhD thesis, Waikato University, 1981); R P Boast The Hot Lakes: Māori Use and Management of Geothermal Areas from the Evidence of European Visitors (Report to the Waitangi Tribunal, Wai 1200, Doc A24, 1992); R J Keam Tarawera: The Volcanic Eruption of 10 June 1886 (published by the author, Auckland, 1988); D M Stafford The Founding Years in Rotorua (Rotorua District Council and Ray Richards, Rotorua and Auckland, 1986).

42 Fenton, above n 40.

43 Fenton Agreement (25 November 1880) (Archives New Zealand, Wellington, MS translation on MA 13/79) cl 1 . 
investigation. Following the survey, the Pukeroa block was to be cut up into sections and leased, rather than sold, with the income to be paid to the Māori owners. At the time this was a highly innovative proposal and a significant departure from standard practice. The leases were to be sold by auction in Auckland and were to be for a period of 99 years. The agreement made special provision for the hot springs and thermal areas by stipulating that "all the medicinal waters within the Town shall be Public Reserves under the management of the doctor, who may make laws regulating their use". ${ }^{44}$ The written agreement drawn up at Ohinemutu was then formally ratified by the Crown. Endorsed on the Māori text of the agreement one finds the following: ${ }^{45}$

In pursuance of the Thermal Springs District Act 1881, and in exercise of the powers conferred on me by the $5^{\text {th }}$ section of the said Act, I hereby contract with the Tribe of Ngāti Whakaue in terms of the above written instrument.

Dated the $16^{\text {th }}$ day of February 1882

Signed: Arthur Gordon, Governor.

The Fenton Agreement thus involved concessions on both sides. Ngāti Whakaue agreed to put up with the Native Land Court so that Pākehā residents could get secure titles. On the other hand, the Government agreed that these titles would be by way of leasehold tenures only, and that Māori would receive the benefit of the rents. Attempts were made to ensure that the thermal springs were to be available for all. To give the agreement legal effectiveness, the Thermal Springs District Acts were passed in 1881 and 1883. The Government, however, used the agreement as a springboard for granting to itself monopoly land purchasing rights in a vast region of the Central North Island, only a small fragment of which had any connection with Ngāti Whakaue. The Native Land Court sat to hear the Pukeroa-Oruawhata case in 1881, which was inevitably followed by a flood of cases as the resistance of Te Arawa to the Court, so tenaciously maintained until then, dramatically collapsed. The leasing scheme failed largely because of the economic depression of the $1880 \mathrm{~s}$, compounded at Rotorua by the eruption of Mt Tarawera in 1886. The hoped-for benefits for Ngāti Whakaue failed to eventuate. Yet the agreement remains vitally important to Ngāti Whakaue and to Te Arawa as a whole. It was on the basis of breaches of the Fenton Agreement, rather than of the Treaty of Waitangi that the Crown entered into a historic settlement with Ngāti Whakaue in 1992.

\section{B The King Country Negotiations and Agreement (1883-1885)}

The negotiations which ended the independence of the King Country (Rohe Potae), the "independent state two-thirds the size of Belgium" in the middle of the North Island that "not all

44 Fenton Agreement, above n 43, cl 3.6.

45 Fenton Agreement, Māori text (Archives New Zealand, Wellington, MA 13/72). 
historians have noticed", ${ }^{46}$ were commented on briefly in the Waitangi Tribunal's Pouakani Report, released in $1993 .{ }^{47}$ The agreement, supposing there was one, and the surrounding negotiations have now been subjected to a full analysis in some important reports prepared for the Waitangi Tribunal by Cathy Marr as part of the Waitangi Tribunal's Rangahaua Whanui research programme ${ }^{48}$ on behalf of the claimants in the National Park and Whanganui Inquiries, ${ }^{49}$ and by Dr Donald Loveridge on behalf of the Crown. ${ }^{50}$

The current Waitangi Tribunal inquiries are not, however, the first occasion at which the events in the King Country in the 1880s have been subjected to later official scrutiny. In $1953 \mathrm{Dr}$ A H McLintock, a distinguished scholar and newly-appointed Parliamentary Historian, was commissioned to write a report on whether or not a "sacred pact" had ever been entered into between the Crown and the King Country leadership. The context for this inquiry was actually that of liquor licensing: the King Country was a "dry" area and Māori wanted it to stay that way, arguing that the prohibition of the sale of liquor was one of the solemn undertakings agreed to by the Crown in the negotiations that took place from 1882-1885. McLintock concluded that there was no "solemn pact or pledge" binding on subsequent New Zealand governments, ${ }^{51}$ but this can be said to be a conclusion of law as much as it is one of history, and one which arguably takes insufficient account of the Māori understanding of what was agreed. The government accepted McLintock's findings and the King Country was opened to the sale of liquor.

There is no one single text that can be said to be the "Aotea Agreement". Rather, between 1882 and 1885 there was a complex series of discussions between two successive Native ministers, John

46 James Belich The New Zealand Wars (Auckland University Press, Auckland, 1986) 306. Belich notes that the independent King Country statelet may have covered as much as 7,000 square miles.

47 Waitangi Tribunal Pouakani Report: Wai 33 (Brooker and Friend Ltd, Wellington, 1993) [Pouakani].

48 Cathy Marr The Alienation of Māori Land in the Rohe Potae (Aotea Block), 1840-1920 (Waitangi Tribunal, Rangahaua Whanui District Report 8, Wellington, 1996). The Rangahaua Whanui research programme of the Waitangi Tribunal was commenced in 1993 to provide a series of background reports both by geographical region and by theme. See Tim Shoebridge Waitangi Tribunal Bibliography: Tribunal Reports, Research Reports and Other Publications (Waitangi Tribunal, Wellington, 2006).

49 Cathy Marr The Waimarino Purchase Report (Wai 1130, Doc A43, 2004) and Summary and Response to Statement of Issues (Wai 1130, Doc A43(a), 2006).

50 D M Loveridge The Crown and the Opening of the King Country 1882-1885 (Report for the Crown Law Office, Wellington, 2006). This report is yet to be presented in evidence and some its conclusions are likely to be tested by a number of the claimant groups in the National Park Waitangi Tribunal regional inquiry, and also in the Whanganui and King Country inquiries should this report be tabled in evidence by the Crown in those inquiries, as is likely. This issue is thus very much a live one before the Waitangi Tribunal at the present time and for this reason will be discussed only briefly in this article.

51 See A H McLintock "Liquor in the King Country" [1953] AJHR H-25. McLintock was a well-known and respected historian, best-known as author of The History of Otago (Otago Centennial Historical Publications and Whitcombe and Tombs, Dunedin, 1949). 
Bryce and John Ballance, and various sections of the King Country leadership, recorded in documents of various kinds. The key steps appear to be: firstly, an agreement between Bryce and some of the King Country chiefs relating to surveys and the completion of the North Island main trunk railway of March 1883; a Parliamentary petition of June 1883 which evidences the wishes and hopes of the chiefs; a further meeting and agreement of 19 December 1883 relating to an external boundary survey of the region; and, following a change of government in 1884, yet further negotiations between the chiefs and the new Native Minister in the Stout-Vogel Government, John Ballance, that took place in 1884 and 1885. At the present time it is in issue in the Waitangi Tribunal whether these agreements should be seen as evidencing or embodying a solemn compact which was afterwards breached, or whether there was a series of interim understandings which the government on the whole adhered to. I do not express an opinion here, and not until the Waitangi Tribunal has reported on the National Park, Whanganui and King Country inquiries will the Tribunal's final view on this complicated matter be available. That may not of itself settle the matter, of course, given that the government is under no formal obligation to accept and act on the Tribunal's findings, and often does not. ${ }^{52}$

Aspects of the agreements were further formalised in statute by section 3 of the Native Land Alienation Restriction Act, passed on 10 November $1884 .{ }^{53}$ The legislation set up a pre-emptive regime similar to that already in force in the Rotorua-Taupo area and later to be established in Te Urewera. In the Waitangi Tribunal's words, the Act "effectively reimposed a Crown right of preemption of the lands of the Rohe Potae". ${ }^{54}$ This meant that no private purchasers were allowed to buy land in the Rohe Potae district. No Māori owner was allowed to enter into any private sale transaction. ${ }^{55}$ Section 7 of the Act specifically allowed the Crown to purchase land within the Rohe

52 As, for instance, in the case of the Waitangi Tribunal's Report on the Crown's Foreshore and Seabed Policy: Wai 1071 (Legislation Direct, Wellington, 2004). See R P Boast Foreshore and Seabed (LexisNexis, Wellington, 2005) 85-91 [Boast Foreshore].

53 This states

After the coming into operation of this Act, no person shall, either by himself or his agent, directly or indirectly, negotiate for, purchase or acquire, any contract or agree to purchase or acquire, from any Native, or from any person on behalf of any such Native, any Native land within the territory described in the Schedule to this report.

The land in the Schedule is essentially the entire Rohe Potae, King Country or Aotea block: see Pouakani, above $\mathrm{n} 47,255$ map 7.1 .

54 Pouakani, above n 47, 112; see Native Land Alienation Restriction Act 1884, s 3. The Act was repealed by the Native Land Administration Act 1886; a pre-emptive regime was then restored by section 5 of the North Island Main Trunk Railway Loan Application Act 1886 and later as amended by the North Island Main Trunk Railway Loan Application Amendment Act 1889. See also Bruce Stirling Taupo-Kaingaroa Nineteenth Century Overview (Wai 1200, DocA71, 2004) 1149-1150.

55 Native Land Alienation Restriction Act 1884, s 4. 
Potae (which included the Tauponuiatia block, separately investigated by the Native Land Court from the rest of the Rohe Potae block) which indeed it did on a massive scale virtually as soon as the various sections of the block were investigated by the Native Land Court. Whether this massive pre-emptive purchasing amounted to a breach of the spirit and intent of the Aotea compact is one of the main issues confronting the Tribunal in its National Park, Whanganui and King Country inquiries.

One can nevertheless say that the end of the history of the King Country was by way of a negotiated agreement, that this arose out of high-level negotiations conducted by the Crown and a number of influential Māori leaders, that it was given effect to (at least to an extent) in statute, and that the agreement continues to be of significance today, its status and interpretation being a matter of high importance in three crucial Waitangi Tribunal regional inquiries.

\section{Negotiations Between the Crown and Te Urewera}

The 1895 agreement between Tuhoe and some other groups of the Urewera region and the Crown is probably the best-known of the three major late $19^{\text {th }}$ century regional negotiations. By the 1890s just one major bastion of Māori de facto autonomy remained: the vast Urewera region in the eastern North Island. This was a remote and largely mountainous area, noted for its spectacular scenery, harsh mountain climate and dense forests. The area was inhabited by a number of iwi and hapu whom it is customary to refer to today as "Tuhoe", but who in fact were a conglomerate of distinct but connected groups. The area was notable also for its pronounced Māori political and religious autonomy. The government's writ did not run in the area, although reasonably amicable working relationships were established during the 1870 s and 1880 s between the Urewera chiefs and government representatives stationed around the Urewera perimeter, principally the resident magistrates at Opotiki and Wairoa. Even today Te Urewera preserves a sense of separateness and isolation from the rest of the North Island.

After the wars the area had been left to its own devices. In 1871-1872 the Native Minister, Sir Donald McLean, appears to have formally recognised the area's regional autonomy. ${ }^{56}$ Professor Binney has characterised McLean's agreement as "a contract made between Donald McLean and Tuhoe's leaders ... for the Urewera to become a self-governing region". ${ }^{57}$ Subsequent governments, however, left Te Urewera alone, not out of any sense of being bound by whatever McLean was believed to have agreed, but rather for the reason that there was no pressure on the government to

56 See Judith Binney "Te Mana Tuatoru: the Rohe Potae of Tuhoe" [1997] 31 NZJH 117. The key documents are the letters from the Urewera chiefs Te Makarini, Paerau and others to McLean of 9 June 1872, Te Whenuanui, Paerau "and all the tribe" to the government, 9 June 1872, and Paerau to McLean, 10 June 1872, all in [1872] AJHR F-3A, 28-30.

57 Judith Binney Encircled Lands: Part Two: A History of the Urewera 1878-1912 (Wai 894, Doc A15, 2002) 1 [Encircled Lands Two]. 
open up the area at the time. ${ }^{58}$ During the 1870 s and 1880 s the Urewera tribes, united as the "Union of Mataatua", managed their affairs through a Council, established in 1872 and known as Te Whitu Tekau (Seventy). Its secretary was a man named Te Ahikaiata. The Union did its best to keep the colonial State at arms length. Roads, surveys, land sales, leases and mineral prospecting were banned. Europeans could not enter the area without permission, and if they did they were firmly escorted beyond the borders. The Union, however, was "a peaceful organisation" ${ }^{15}$ and did not seek confrontation with the government.

Although the Tuhoe were left alone, the Urewera region was certainly subjected to the pressure of being ever closely hemmed in by the Native Land Court and government purchasing. By the late 1870s the Court was investigating blocks along the western and northern edges of Te Urewera. By this time the region had already been hemmed in by the Eastern Bay of Plenty and Mohaka-Waikare confiscations, and by a complex process of quasi-confiscation and purchase in the upper Wairoa area during the early 1870s. In June 1877 the Waimana block, just outside the northern Urewera boundary, was investigated by the Court, and then reinvestigated in $1880 .{ }^{60}$ Waiohau, a block on the northwestern side of Te Urewera belonging mainly to the Patuheuheu and Ngāti Haka hapū of Tuhoe, was investigated and partitioned by the Native Land Court in 1878. ${ }^{61}$ The large Heruiwi block, which lay on the eastern side of the Rangitaiki river, was also investigated and partitioned by the Court in $1878 .^{62}$ A similar process of encroachment took place on the southern and eastern sides of the Tuhoe rohe potae as well. ${ }^{63}$ These investigations of title were often followed by very rapid and substantial Crown purchases. Examples are the 20,910 acres of Heruiwi 1 awarded to the Crown in 1881, a further 73,221 acres in Heruiwi and Heruiwi 4 acquired by the Crown on partition during the 1890s, and 10,111 acres of Whirinaki 1(1) acquired by the Crown from Ngāti Manawa in $1895 .{ }^{64}$

58 See Anita Miles Te Urewera (Waitangi Tribunal, Rangahaua Whanui District 4, Wellington, 1999) $237-238$.

59 John Hutton and Klaus Neumann Ngati Whare and the Crown (Wai 994, Doc A28, 2001) 74.

60 (1877) 1 Opotiki Minute Book 16-63. On the Waimana hearings see Jeffrey Sissons Waimana Kaaku: A History of the Waimana Block (Wai 894, Doc A24, 2002) 31-59.

61 Waiohau Investigation of Title (1878) 1 Opotiki Minute Book 114, 115.

62 Heruiwi Investigation of Title (1878) 1 Optiki Minute Book 92, 93. For an analysis of this case see Tracey Tulloch Heruiwi (Wai 894, Doc A1, 2001) 92-93.

63 On these and other blocks see Binney Encircled Lands: Part One (Wai 894, Doc A12, 2002) 284-288 and 308-323; Cathy Marr Crown Impacts on Customary Interests in Land in the Waikaremona Region in the Nineteenth and Early Twentieth Century (Wai 894, Doc A52, 2002) 137-219; Miles, above n 58, 204-217; Vincent O'Malley The Crown and Ngati Ruapani: Confiscation and Land Purchase in the WairoaWaikaremoana Area 1865-1875 (Unpublished Report to the Waitangi Tribunal for the Patunamu State Forest Claim, 1994).

64 (1881) 2 Opotiki Minute Book 155-56; R Boast Ngati Whare and Te Whaiti-nui-a-Toi: A History (Wai 894, Doc A27, 1999) 91-92; Tulloch, above n 62, 70-90. 
Tuhoe chiefs thus found themselves being forced to engage with the Native Land Court. In the Heruiwi 4 case in 1890 the Tuhoe chief Tutukangahau advanced a claim to this block on behalf of Nga Poitiki; the other claimants included Ngāti Manawa, Ngāti Apa and Ngāti Hineuru. He also appeared in the Whirinaki case, heard by the Native Land Court in 1890, advancing a claim to it on behalf of the important Tuhoe Ngâti Tamakaimoana, but the claim was dismissed by Judge Gudgeon. ${ }^{65}$ Sooner or later, it seemed, the Native Land Court was going to break into the core Tuhoe territories. It may have been this threat, as much as difficulties with surveys, roads and other government pressures, which led the chiefs of Te Urewera, mainly although not exclusively Tuhoe, to enter into negotiations with Seddon, the Liberal Prime Minister, in $1895 .{ }^{66}$

In 1895 a delegation of Urewera chiefs visited Wellington and stayed for the whole of the Parliamentary session: "They interviewed the Premier and the Government and the Native members as to what they wished to be preserved in regard to their land, and what should be done in connection with their country." 67 There were meetings on 7 September, where members of the delegation met with the Prime Minister (Seddon), James Carroll and Wi Pere, and on 23 September. ${ }^{68}$ The main outcome was Seddon's memorandum of 25 September. ${ }^{69}$ This was addressed to "the persons who came hither to represent Tuhoe, and who have addressed me with reference to certain matters affecting the tribe".

In effect the Urewera tribes made a cession of their de facto sovereignty in return for certain promises made by the government of the day on behalf of the Crown. The main points supposedly agreed to, as identified by Seddon, were: (a) an external survey of the Urewera block; (b) internal subdivisions to be carried out by a Commissioner, rather than the Native Land Court; and (c) the establishment of a process of self-government through a General Committee representing the various iwi and hapu of the region. The government also promised to establish native schools in the area, construct roads (and thus provide opportunities for contract work for the near-destitute people of the area), introduce fish species such as trout, assist with the promotion of tourism, and allow the

65 See Tracy Tulloch Whirinaki (Wai 894, Doc A9, 2002) 29; see also (1890) 3 Whakatane Minute Book 100, 102 .

66 For detailed narratives of the events leading up to the 1895 negotiations see Encircled Lands Two, above $\mathrm{n}$ 57; Cecilia Edwards The Urewera District Native Reserve Act 1896: Part 1: Prior Agreements and the Legislation (Wai 894, Doc D7(a), 2004)

67 (24 September 1896) 96 NZPD 158.

68 The most detailed consideration of the negotiations is by Edwards, above n 66, 165-201.

69 An English-language version of this agreement was reprinted as schedule II of the Urewera District Native Reserve Act 1896. This text is the one cited above, unless otherwise indicated. There are a number of sources which relate to the negotiations, however, which have been usefully identified by Cecilia Edwards (see Edwards, above n 66, 165). There are three texts of the 25 September memorandum, one in English and one in Māori, both on J1, 1896/1073, Archives New Zealand, Wellington as well as the official text printed as Schedule II to the Act. 
people of Te Urewera to receive mining royalties. The terms of the agreement reveal that Tuhoe and the other tribes were seeking, above all, to modernise their regional economy on their own terms.

\section{The Urewera District Native Reserve Act 1896}

The Urewera District Native Reserve Bill, the legislation implementing the 1895 agreement, was first introduced into Parliament on 30 October 1895 and was reintroduced the following year when it was passed pro forma and sent to the Native Affairs Committee. After extensive amendment, the Bill was introduced by Carroll on 24 September 1896 for its second reading. Carroll explained to the House that its main objective was to set aside Te Urewera as a Native Reserve: ${ }^{70}$

The object of the Bill is to constitute a reserve in that part of the country known as the Urewera district.

It affects an area of about six hundred and fifty thousand acres. ... The land has been subjected to a topographical survey, and it has been ascertained that it is not fit, as other lands in this country, for settlement in any shape whatever.

The legislation was designed to give effect, said Carroll, to the agreement negotiated between the Urewera people and the Crown, whereby the Urewera lands could be protected from alienation. ${ }^{71}$ Carroll explained to Parliament why the Native Land Court had been dispensed with: there were "no European interests involved"; it was necessary that the investigation be "according to Māori law, usage and custom" and for the "complications and dissatisfaction" so typically associated with the Native Land Court to be avoided. Nevertheless, the programme that was envisaged for Te Urewera was one of a complete individualisation of title. ${ }^{72}$

The other principal speech in favour of the Bill was made by the Prime Minister, who had been closely involved in the negotiations of the previous year. ${ }^{73}$ Seddon's first point was that the legislation gave effect to the promise, made by McLean years before when Native Minister, to protect the Urewera lands from alienation. Second, contrary to the general impression that $\mathrm{Te}$ Urewera "was a land flowing with milk and honey", in fact "very little of it is at all suitable" for settlement by Europeans. Third, the legislation was a grant of Māori self-government, and was desirable for that reason. Fourth, the agreement of 1895 and the proposed legislation, while protecting local autonomy, recognised the authority of the Crown and the New Zealand government. It was better that the region be set aside by an Act of Parliament than that the government's representatives be openly defied: ${ }^{74}$

$70 \quad$ (24 September 1896) 96 NZPD 157.

71 (24 September 1896) 96 NZPD 157.

72 For a somewhat different emphasis, see Edwards, above n 66, 247-249.

73 (24 September 1896) 96 NZPD 166.

74 Edwards, above n 66, 167. 
If matters had continued as they were it [Te Urewera] was practically a reserve, but not a reserve supported by legislation; it was a stronghold of the people who were determined that Europeans should not be in their midst - that our Courts and our present course in respect to Native lands procedure should not obtain in their part of the colony ... I say it would be much better to have a reserve such as this is made now, with the sanction and approval of our Parliament, with the mana of the Queen admitted freely and without the slightest reservation, than to have, as we had only a few years ago, a representative of Her Majesty the Queen going to the borders of the Urewera Country and then turning back, deeming it not to be advisable to proceed further.

Cynics might say that in this passage Seddon reveals the real objective of the legislation: to end the de facto independence of Te Urewera, an annoying affront to the government, and bring it under effective the sovereignty of the Crown. It is true that the legislation did in effect end Te Urewera independence, and it is also true that the 1896 experiment would certainly not have been embarked on if Te Urewera had actually been wanted for Pākehā settlement. The legislation also imposed on Te Urewera an interventionist and disruptive system of title allocation. Nevertheless, for all its limitations the 1896 Act did also concede real autonomy, protected the Urewera people from the risk of Crown purchasing (for a while) and attempted to treat the Tuhoe people as partners in the development of their own region.

The Urewera District Native Reserve Act was passed on 12 October 1896. The Act is described in its Long Title as "an Act to make provision for the ownership and local government of the Native lands in the Urewera District". The Preamble states:

Whereas it is desirable in the interests of the Native race that the Native ownership of the Native lands constituting the Urewera District should be ascertained in such manner, not inconsistent with Native customs and usages, as will meet the views of the Native owners generally and the equities of each particular case, and also that provision should be made for the local government of the said district ...

The 1895 agreement and the 1896 Act were both framed in a mood of relative generosity on the part of the government and a willingness to make concessions in return for a solution to the embarrassment of continuing de facto Urewera independence. The legislation was "sold" to Parliament on the basis that Te Urewera was useless for Pākehā settlement. When Carroll introduced the Bill he was, as already noted, very careful to emphasise that the region could not be settled by Pākehā farmers. The land was rugged and the soils were poor. This emphasis placed by Seddon and Carroll on Te Urewera's lack of value for settlement was designed no doubt to deflect potential opposition to the legislation; that it was "locking up" valuable land. As long as officials and politicians believed that Te Urewera was of no value, the special arrangements for the area continued. By the second decade of the $20^{\text {th }}$ century, however, the government's views had changed. Massey's Reform Government was heavily farmer-backed and was responsive to pressure from farming organisations and county councils. By 1915 the Lands and Native Departments had rejected Carroll and Seddon's bleak assessment of Te Urewera and had come to the conclusion that it might be worth acquiring after all. In this the Departments had the full support of W H Herries, who 
became Native Minister in 1912. In this new climate, the guarantees of 1896 were soon forgotten as the Native Land Court was introduced to the region and the Crown embarked on an aggressive programme of undivided share-buying of the Urewera block. Most of the region passed into Crown title during a massive title consolidation scheme during the 1920s.

\section{ANALYSIS}

\section{A A Hierarchy of Agreements?}

As noted above, the Government of New Zealand entered into hundreds of elaborate, written agreements with Māori after the Treaty of Waitangi. At first sight it might seem as if these fall into an obvious hierarchy, with the pre-1862 deeds of purchase having much less of the character of "treaties" - being essentially land conveyances - than do the three regional agreements with the King Country Tribes, with Te Arawa and with the iwi and hapū of Te Urewera. What distinguishes the latter is the close involvement of the national government in the process. The King Country negotiations were carried out by two Native Ministers, Bryce and Ballance; the Fenton Agreement was negotiated by the ex-Chief Judge of the Native Land Court answering directly to the Native Minister, Rolleston, and was ratified by the Governor-General; and the Tuhoe negotiations involved a series of meetings in Wellington in which a number of Ministers of the Crown and the Prime Minister, Seddon, were directly involved. These agreements were also given effect to in statute, indicating that as far as the Crown was concerned the agreements were certainly significant and solemn obligations which obliged the government of the day to give them legal effect. Most importantly, the content of the agreements related to a wide range of matters other than land, and contained respective promises between the parties relating to their relationships in the future.

The pre-emptive deeds of purchase, at first sight, bear none of these characteristics. Negotiations were carried out by Land Purchase Officers and did not involve central government. The deeds were not implemented in statute, but seem to have been regarded in some sense as self-executing; although it was standard practice, once a deed had been concluded, to formally proclaim the area sold or ceded by deed to be Crown land, following which the land was regarded liable to Crown grant. The content of the purchase deeds was usually narrow in scope and related essentially to defining a tract of land to be ceded to the Crown, together with traversing such ancillary matters as access to sacred sites and food-gathering places, surveys, and the extent and means of identification of reserves. Nevertheless, the pre-emptive purchase deeds do exhibit a considerable degree of variety, with some of them arguably embodying some kind of constitutional relationship with the Crown and others falling much more obviously into the category of straightforward conveyances. A possible example of the former are the Ngai Tahu deeds, which relate to very large areas in the South Island and were accompanied by a considerable amount of discussion about reserves and other questions. ${ }^{75}$ Of the latter the numerous small purchases carried out by John Rogan as District

75 An example being Kemp's Purchase, or the Canterbury deed, of 1848, which relates at least to the entirety of Canterbury, although the boundaries are a matter of debate: see Ngai Tahu Deeds, above n 20, 81-98. 
Land Purchase Commissioner in the Kaipara region after $1857 .{ }^{76}$ Some of the purchase deeds can be very plausibly said to either embody, or form part of, a more general agreement between the parties which was not confined to the conveyance of land. Moreover, as O'Malley has argued, Donald McLean, the government's chief Land Purchase Officer, saw himself as the agent of the Crown quite independently of the colonial regime and his task as essentially one of negotiating treaties. ${ }^{77}$ James Belich has gone as far to suggest that the purchase deeds can be seen as the practical working-out of the Treaty of Waitangi at the local level: ${ }^{78}$

Perhaps these local partnerships, created by land sale and Pākehā settlement, and endorsed by sale ceremonies, treaty signings and acceptance of magistrates and the like, were a fifth, living version of the treaty. By no means all Māori entered into them, but the many who did were, voluntarily and in full possession of their faculties, accepting large-scale Pākehā settlement and the substantial advent of the colonial state.

Texts such as the Fenton Agreement clearly do appear to have a public law character. They are not private law deeds or sale agreements - a categorisation which seems to accurately characterise many of the pre-emptive deeds of session. An ordinary purchase deed such as the Matawhero purchase deed of 1862 (this being a block of 5480 acres in the South Kaipara district) ${ }^{79}$ appears to be self-acting, in that it does not require any further step for it to become effective in municipal law. The same is not true of the confiscation and regional pre-emptive agreements, which in all cases required separate statutory provisions to give them effect, a characteristic which these documents share with agreements being negotiated at the present day, as will be seen. Arguably, it does no harm to their essential nature for them to be called "treaties". As in the case of ordinary treaties, the Crown regarded itself as in some sense bound to translate the outcomes of diplomacy into legally effective provisions by statute.

Another possible "Treaty-like" purchase deed is the Ahuriri deed (Hawke's Bay) of 1851: see generally "Treaty-making", above n 6.

76 See Kaipara, above n 7, 166-176. The Tribunal found that these purchases "were not excessive, in that the areas purchased were largely determined by the rangatira involved, who were actively encouraging $\mathrm{P}$ settlement" and that while "Crown officials did make general statements about the expected benefit for Māori of P settlement on lands purchased from Māori", there was "no substantive evidence that specific promises were made in southern Kaipara" (at 175).

77 See "Treaty-making", above n 6, 139, where he argues that "McLean's frequent use of the term 'treaty' when describing land-purchase deeds negotiated with Māori appears to have been quite deliberate". McLean often does refer to the Crown and Māori as being "in treaty", but sometimes this might mean, in the context of the time, nothing more than "in negotiation": on other occasions it could mean rather more.

78 Making Peoples, above n 6, 202.

79 Kaipara, above n 7, 171. 
As the above discussion indicates, some of the purchase deeds, and more certainly all of the confiscation and pre-emptive district agreements, are texts of some significance in New Zealand's legal history and public law, as they were the means by which the Crown's practical sovereignty was extended over reasonably large parts of the North Island. Considered from the standpoint of the Crown, these are important agreements. From the standpoint of the Māori signatories, their significance is certainly greater still; they are the foundation of relationships with the New Zealand State that endure to this day and a benchmark by which the Crown's behaviour can be evaluated.

\section{B New Zealand State Practice}

To revert to a point made at the start of this article, at no point did the New Zealand government ever assume that any of the post-Treaty of Waitangi agreements analysed above ever amount to an extension of the Crown's legal sovereignty over New Zealand. The extension of the Crown's legal sovereignty, as opposed to the historical reality, was never seen as piecemeal. (That may not necessarily be how Māori saw things, of course). Considering the matter of "status" more generally, State practice seems to have been one of avoiding the issue of legal status by using Parliament as the principal means by which the various agreements could be given legal effect. So, as seen, the Mohaka-Waikare agreement led to the Mohaka and Waikare Districts Act 1870, the Fenton Agreement to the Thermal Springs Acts of 1881 and 1883, the Rohe Potae negotiations to the Native Land Alienation Restriction Act 1884, and the Urewera agreement to the Urewera District Native Reserve Act 1896. In this sense, the various agreements do in fact resemble treaties, in that just as with international treaties - a statute is needed to translate them into domestic law; this still being the current constitutional position of the Treaty of Waitangi itself, as well as being the practice with the Crown-Māori agreements being drawn up at the present day.

If the confiscation and regional agreements are to be seen merely as vehicles for implementing statutes, the reality today is that the implementing statutes have now in all cases been repealed. That has not had the effect of terminating the agreements. That the Māori parties affected by the various agreements would regard them as effective and binding today is to be expected; what is perhaps less to be expected is that the Crown, or more precisely the New Zealand government, also sees the agreements as having some kind of continuing effect. Not only that: the Crown is prepared to offer redress for their breach, seen most clearly in the case of a settlement entered between the Crown and Ngāti Whakaue, the Crown's principal partner in the case of the Fenton Agreement.

\section{Waitangi Tribunal Analysis}

The Waitangi Tribunal has already considered the King Country, or Aotea Agreement in its Pouakani report. That claim was not about the King Country negotiations as such, but rather was concerned with complex questions relating to surveys and survey liens in subdivisions of the Tauponuiatia block. ${ }^{80}$ The King Country agreement was only of general relevance to the

80 Along with Mr P R Heath, I acted as counsel for the claimants in this inquiry in 1989. 
circumstances by which the Tauponuiatia block came to be investigated by the Native Land Court in 1886. In the Pouakani report the Tribunal reviewed evidence relating to the King Country negotiations in a neutral way without making any findings, and concluded as follows: ${ }^{81}$

There are many aspects of government negotiations with Ngāti Maniapoto and the nature of the

"Maniapoto compact" with the Crown which are beyond the scope of this report. The issue relevant to

the Pouakani claim is the matter of survey of the Aotea block, and in particular the boundary between

Aotea and Tauponuiatia West block, a subdivision of Tauponuiatia lands of Ngāti Tuwharetoa.

Post-Treaty agreements or pacts have, however, now begun to surface more directly in claims before the Tribunal. One of the issues discussed in a Waitangi Tribunal's recent major report, Kaipara, ${ }^{82}$ was whether there was an "alliance" between the Crown and Ngāti Whātua, one of the principal Māori iwi of the Auckland isthmus. ${ }^{83}$ An alliance, obviously, can only arise by agreement. Counsel for Ngāti Whātua argued that this alliance was "entered into as a mutually beneficial arrangement imposing obligations on both parties" in 1840. Competing expert evidence on the "alliance" was presented by two historians: Philippa Wyatt on behalf of the claimants and Dr Donald Loveridge on behalf of the Crown. ${ }^{84}$ The evidence for the "alliance" was largely circumstantial in that it was inferred from the circumstances of the early settlement of Auckland, rather than on the basis of any clear evidence of negotiations and an agreement, and there was no written text to which the claimants could point. As the Tribunal summarised the argument: ${ }^{85}$

The Crown ... needed Ngāti Whātua, it was argued, because they had the land around Auckland which the Crown needed for Pākehā settlement. More specifically, Ngāti Whātua supplied the land which the Crown needed for the colonial capital at Auckland. The claimants say that this land was 'gifted' by Ngāti Whātua, but also maintain that, even if it was not gifted, Ngāti Whātua's agreement to make this land available was crucial to the formation of the alliance with the Crown.

The claimants made this argument not because they were interested in historical revisionism, but with the very practical objective of adding some ammunition to their claim against the Crown. Not only was the Crown in breach of the principles of the Treaty of Waitangi, it was also, separately and

81 Pouakani, above n 47, 108.

82 Kaipara, above n 7.

83 This issue was raised by the Wai 312 claimants, one of 33 claims considered by the Tribunal in Kaipara, above $\mathrm{n} 7$. Wai 312 is a claim by Takutaimoana Wikiriwhi and others concerning West Auckland lands. The Waitangi Tribunal does not as a rule deal with historic claims singly, but groups them together into inquiry districts and then inquires into and reports on a number of claims in a single inquiry and report.

84 Philippa Wyatt Ngati Whātua o Kaipara ki te Tonga and the Crown, 1840-1869 (Wai 674, Doc F4, 1998); and Donald Loveridge Ngati Whātua and the Crown - The First Quarter-Century: An Appraisal of the Wyatt Report (Wai 674, Doc O4, 2001).

85 Kaipara, above n 7, 153 
additionally, in breach of its alliance with Ngāti Whātua. ${ }^{86}$ The Crown, needless to say, strongly opposed the claim that it had an "alliance" of any kind with Ngāti Whātua. The Tribunal dealt with the argument by emphasising that any suggestion that the Crown had particular obligations to any one iwi arising from an alliance - or, presumably, any other kind of pact - is "highly problematic": ${ }^{87}$

The Treaty [of Waitangi] provides the same protections and guarantees to all Māori individuals and groups. Even if a special relationship between the Crown and a particular Māori group could be demonstrated to have existed, such a relationship should have no bearing on the Crown's Treaty responsibilities to that group. Nor should the Crown be considered to have greater responsibilities towards Māori groups construed as 'loyal' than to those classified as 'rebels', or towards those who sold land to the Crown as opposed to those who exercised their Treaty-guaranteed rights not to sell land. Article 3 of the Treaty extended the rights and privileges of British subjects to all Māori.

As the Tribunal noted, its own jurisdiction under the Treaty of Waitangi Act 1975: ${ }^{88}$

... requires the Tribunal to consider claimed breaches by the Crown against the principles of the Treaty of Waitangi ... We are not required to consider any alleged relationship beyond the terms of the Treaty itself. We have not been persuaded, therefore, that the conceptual gloss of an 'alliance' has significantly altered the historical context of the Crown's actions or inactions in the Kaipara inquiry district, or our inquiry district.

It is certainly the case that the Tribunal's statutory responsibility is to evaluate the Crown's actions with reference to the principles of the Treaty of Waitangi. It does not have to follow, however, that applying the principles of the Treaty of Waitangi means that particular arrangements, promises or "alliances" become irrelevant, need not be kept or are not the Waitangi Tribunal's concern. Arguably the Tribunal could consider such special agreements while continuing to act within its jurisdiction. Why cannot it be said, for example, that implicit in the principles of the Treaty of Waitangi is the notion that if the Crown makes promises in a later pact or agreement then it should keep them? In this sense, a failure to adhere to a later specific pact is a breach of the general, or overarching, pact of the Treaty of Waitangi.

86 See Kaipara, above n 7, 153-154. The claimants argued that Ngāti Whātua had kept its part of the bargain by making land available to the Crown, by "remaining loyal to the Crown and working in cooperation with Crown institutions" (at 153) and by making particular gifts of land to the Crown. On the other hand, it was said, the Crown had breached its obligations by "failing to ensure that Ngāti Whātua were given political or legal equality", by "undermining Ngāti Whātua's ability to exercise tino rangatiratanga" (at 164) and neglecting "to provide the promised services, infrastructure, and settlement at a time when Ngāti Whātua were still in a strong position to benefit from these" (at 164).

87 Kaipara, above n 7, 159.

88 Kaipara, above n 7, 159. 
The Tribunal's remarks in Kaipara, however, seem to be going rather further than the Tribunal's statutory jurisdiction and extend to the desirability of having recourse to other agreements as a matter of law and policy generally. Without wishing to read too much into the Tribunal's comments, the Tribunal has arguably gone rather too far in the passages cited above and has failed to analyse adequately a number of important points. Surely, in the case of the Urewera agreement of 1895 which certainly does embody commitments which the Crown did not extend to other Māori but which, rather, arose from the agreement itself as negotiated between the parties and embodied in a text - that agreement in fact ought to be taken account of in any assessment of the Crown's actions with respect to Tuhoe and other groups of Te Urewera. Does it mean nothing? Does the existence of the Treaty of Waitangi as a kind of constitutional standard now mean that separate later agreements between the Crown and specific Māori groups are unworthy of consideration? That, I would argue, cannot be so, given the seriousness and solemnity of some of these later pacts, that they were certainly regarded as creating obligations at the time, and that both parties appear to consider them as significant today.

The evidence for an "alliance" between the Crown and Ngāti Whātua does appear to be insubstantial - although the importance of the relationship between Ngāti Whātua and the Crown for the success of the Auckland settlement in a broader sense does have some force - and it is therefore understandable that the Tribunal took the position that the possibility of such an alliance did not add anything of significance to Ngāti Whātua's claims against the Crown. The position is rather different with the King Country and Urewera regional agreements. Here there is evidence of prolonged negotiations, concessions by both sides, a text or texts which evidences or embodies the outcome of the discussions, implementing legislation, and efforts by both parties subsequently to adhere to what had been agreed. These agreements are not peripheral to, but central to the Urewera, National Park and King Country inquiries; the Fenton Agreement, if not quite so central to the Central North Island inquiry, certainly featured prominently in evidence and submissions. The Tribunal is going to have to find a means of incorporating a consideration of these later understandings within its particular statutory jurisdiction to report on actions or omissions of the Crown that are contrary to the principles of the Treaty of Waitangi. The way forward lies in the suggestion made above, that the Treaty of Waitangi does not preclude later agreements being made with particular groups, and that the various principles of the Treaty that have been developed by the Tribunal embody the concept that later, particular pacts ought to be kept.

\section{NEGOTIATIONS AND AGREEMENTS OF THE PRESENT DAY: CONTINUED MULTI-TEXTUALISM?}

It is certainly clear that the Crown and Māori have a long history of entering into agreements. This is a process that has not come to an end. In fact it has, if anything, been re-energised over the last twenty years, as New Zealand, along with a number of other countries, has entered into a 
process of negotiation and settlement of a range of historic claims. ${ }^{89}$ (On the other hand, the Foreshore and Seabed Act 2004, whatever might be said in its defence, is arguably at odds with the New Zealand tradition of negotiated settlements, the legislation being enacted in the face of virtually universal Māori opposition). ${ }^{90}$

Contemporary agreements, the legal and constitutional status of which is no less puzzling than historic texts such as the Fenton Agreement of 1880, exist in two main areas: fisheries and land. In the case of fisheries, the two main texts were the Crown settlement offer of October 1988 and a fisheries Deed of Settlement of 1992, both of which were given effect to in statute. ${ }^{91}$ With land claims, there have now been a number of deeds of settlement negotiated between various Māori groups and the Crown, each of which has also been given effect to by an implementing Act. Very substantial sums of money are now finally being paid out to iwi after a decade of inter-Māori wrangling and litigation as to how the commercial fisheries settlement assets should be distributed. Ngā Puhi, for example, have recently received a fisheries settlement allocation of no less than \$67 million. To be eligible for this, however, an iwi is required by law to be a mandated iwi organisation and meet the criteria set out in the Māori Fisheries Act 2004.

The Courts were unable to find a satisfactory means of analysing and giving effect to the fisheries agreements, and it does appear that no established legal category exists into which they can readily be fitted. In the case of the "Sealords" fisheries settlement deed, the New Zealand Court of Appeal concluded in 1992 that whatever the agreement was, it could not be classed as a contract, but was rather "a compact of a political kind, its subject-matter so linked with contemplated Parliamentary activity as to be inappropriate for legal rights". ${ }^{92}$ The 1992 deed committed the New Zealand government to introduce implementing legislation into Parliament, something which the Court of Appeal felt that the Courts could hardly give effect to, and was a clear indication that the agreement could not be classed as contractual. Nor could the Courts inquire into whether the Māori signatories had a mandate for entering into the agreement on behalf all Māori, this being a "political question". ${ }^{93}$ What was clear was that the deed was not binding on all Māori on whose behalf it had purportedly been made: "all that can be safely said", observed Cooke P, "is that the deed was

89 See generally Langton and others, above $\mathrm{n} 12$.

90 Boast Foreshore, above n 52, 85-111; P G McHugh "From Common Law to Codification: the Foreshore and Seabed Act 2004" in New Zealand Law Society Foreshore and Seabed Act, the Resource Management Act and Aquaculture (Wellington, 2005) 1.

91 Māori Fisheries Claims Settlement Act 1989; Treaty of Waitangi (Fisheries Claims) Settlement Act 1992 and the Māori Fisheries Act 2004. See generally R P Boast "Māori Fisheries 1986-1998: A Reflection" (1999) 30 VUWLR 111.

92 Te Runanga o Wharekauri Rekohu Inc v Attorney-General [1993] 2 NZLR 301, 309 (CA) Cooke P for the Court.

93 Te Runanga o Wharekauri Rekohu Inc v Attorney-General, above n 92, 309 Cooke P for the Court. 
negotiated by some responsible Māori leaders and has significant Māori support but also significant Māori opposition". 94

With the development of the government's historic claims settlement policy there has been a sequence of elaborate agreements between the Crown and Māori negotiators. ${ }^{95}$ This is not altogether a new development, as there were a number of earlier settlements in the 1930s and 1940s relating to the title to Lake Taupo and the Rotorua lakes, confiscations made under the New Zealand Settlements Acts, and a number of other land-related problems. ${ }^{96}$ A historian who has investigated this first wave of settlement agreements has written that the evidence: ${ }^{97}$

... does not reveal duplicity or bad faith on the part of either of the partners to the Treaty of Waitangi,

Māori or the Crown. ... Rather, it reveals a determination by both to resolve finally longstanding

grievances in good faith, in accord with the standards and the realities of the time. To conclude

otherwise is to stand accused of ahistoricity.

These earlier agreements had the standard characteristic that they were subsequently given effect to in statute. The same is true of the historic claims settlements negotiated and settled under the negotiation and settlement system that has developed since 1995.

The scale of the current negotiations and historic settlements dwarf anything agreed to in the earlier decades of the $20^{\text {th }}$ century, and the elaborate processes involved are not well-understood by the public at large. The current settlements are not on the basis of restitutio in integrum, and cannot be: how could the government of the day restore to the Tainui people the full value of the confiscated Waikato? But this does not mean that the settlements are inconsequential. Some iwi

94 Te Runanga o Wharekauri Rekohu Inc v Attorney-General, above n 92, 309 Cooke P for the Court.

95 On the negotiation and settlement process of the present day see R P Boast, A Erueti, D McPhail and N F Smith Mãori Land Law (2 ed, LexisNexis, Wellington, 2004) 14-17; C Coxhead "Where Are the Negotiations in the Direct Negotiations of Treaty Settlements?" (2002) 10 Waikato LR 13; R Te K Mahuta "Tainui: A Case Study of Direct Negotiation" (1995) 25 VUWLR 157; P G McHugh Aboriginal Societies and the Common Law: A History of Sovereignty, Status and Self-determination (Oxford University Press, Oxford and New York, 2004) 505-529 [McHugh Aboriginal Societies] (of particular value in setting the current New Zealand process in a historical and international context); A Mikaere "Settlement of Treaty Claims: Full and Final, or Fatally Flawed?" (1997) 17 NZULR 425; New Zealand Law Commission Treaty of Waitangi Claims: Addressing the Post-Settlement Phase (SP 13, Wellington, 2002). Although there is a growing literature, it is not large when set against the scale and importance of the current settlement process.

96 See for example Native Land Amendment and Native Land Claims Adjustmeent Act 1922 (Rotorua lakes); Native Land Amendment and Native Land Claims Adjustment Act 1926 (Lake Taupo); Lake Waikaremoana Act 1971. On the earlier lake and riverbed settlements see generally Boast Foreshore, above n 52, 22-27. Following a Royal Commission of Inquiry into the confiscations, usually known as the Sim Commission (see [1928] AJHR G-7) there were a sequence of settlements of the confiscation or raupatu claims, also impended in statute (for example, Native Purposes Act 1931).

97 Richard Hill Settlements of Major Māori Claims in the 1940s: A Preliminary Historical Investigation (Report to the Department of Justice, Wellington, 1989) 13. 
have already benefited or are going to benefit handsomely from both the historic settlement and fisheries settlements processes. Ngai Tahu has already done very well in terms of its historic settlement, legislated in place in 1998, and will in addition receive a substantial fisheries allocation under the statutory formulae set out in the Māori Fisheries Act 2004: $\$ 170$ million for historic grievances, \$85 million to come under commercial fisheries, giving a total of \$255 million. Measured by the standards of civil litigation in New Zealand - which is essentially what the Treaty settlement process is - this is a substantial outcome. Ngai Tahu are already major players in the South Island economy.

At the present time, claimants and the Crown ${ }^{98}$ jointly prepare a Deed of Settlement, usually a very elaborate text containing lengthy recitals that narrate the history of the negotiations and of the historic events that gave rise to the claim, as well as detailed provisions relating to the return and management of various kinds of assets. Before this, the government first has to accept that the entity seeking to negotiate a settlement with it is a "large natural grouping", and that it has met the requirements for mandating as set out in the official guidelines. The actual negotiations process, which has some affinities with current processes in Canada, ${ }^{99}$ is far too elaborate to be described here, but in brief it involves a sequence of prescribed steps each of which results in a particular type of written agreement: Terms of Negotiation, Agreement in Principle, and Deed of Settlement. Each negotiation takes several years. The final settlement has to be ratified by the group: the "mandate" insisted on by the Crown at the start of the process is a mandate only to negotiate a settlement, not to accept it. The deeds are then implemented in statute. ${ }^{100}$ The Courts, as with the Sealord deed, have had difficulty in characterising the legal nature of a contemporary Deed of Settlement. Given that the negotiation and settlement system itself has no statutory underpinnings, ${ }^{101}$ the Courts have

98 The Crown agency that deals with the negotiation and settlement of historic (pre-1992) claims is the Office of Treaty Settlements, established in 1995 as a separate entity within the Department of Justice. It reports to and advises the Minister in Charge of Treaty of Waitangi Negotiations (MICOTOWN).

99 See Ravi de Costa "Treaties in British Columbia: Comprehensive Agreement Making in a Democratic Context" in Langton and others, above n 12, 133-146; and Maureen Tehan "The Shadow of the Law and the British Columbia Treaty Process: 'Can the unthinkable become common place'?" in Langton and others, above n 12, 147-162.

100 For example, Waikato Raupatu Claims Settlement Act 1995; Ngai Tahu Claims Settlement Act 1998, Ngati Turangitukua Claims Settlement Act 1999, Pouakani Claims Settlement Act 2000; Te Uri o Hau Claims Settlement Act 2002

101 The key text is the Office of Treaty Settlements publication Ka tika a muri, ka tika a mua: Healing the past, Building a Future: A Guide to Treaty of Waitangi Claims and Negotiations with the Crown (Office of Treaty Settlements, Wellington, 2002). This important publication, known as the "red book" (to distinguish it from its predecessor, the "green book") is both a set of guidelines and a summary of various policy decisions already taken at Cabinet level. There is no statute dealing with the negotiation and settlement process, although particular settlements are implemented in statute. 
confined the whole negotiation and settlement process to the realm of policy and politics, and as such not amenable to review by the courts. According to Goddard J in Pouwhare: ${ }^{102}$

The negotiated settlement process and the development of policy in relation to that is not by its nature amenable to supervision by the Courts. The settlement of Treaty grievances involves the exercise of prerogative power and the enactment of legislation and for those reasons is the provision [sic] of Parliamentary sovereignty. There is ample authority relating to similar attempts to challenge what can only be categorised as a highly political process.

This conclusion is understandable, given the absence of any statutory criteria on which a judicial review case would normally be founded. The effect is, that while an earlier process of asset identification and transfer to State-owned enterprises in the 1980 s certainly was amenable to supervision by the courts, as shown by a sequence of major decisions in this area relating to Māori claims based on the principles of the Treaty of Waitangi, the current - and vastly bigger - settlement process operates wholly within the realm of "policy", and the courts have retired from the field. By default, the Waitangi Tribunal is now the only forum where challenges to the government's settlement process by Māori groups unhappy with various aspects of it are able to be heard. Once again, Māori and the Crown are back in the business of concluding high-level political agreements, more elaborately than ever.

\section{SUMMARY AND CONCLUSION: RETHINKING HISTORY AND LAW}

Lawyers are trained to think in terms of cases and statutes. From that standpoint the legal history of the relationship between the Crown and Māori is embodied in key statutes such as the Native Lands Act 1865, or key cases such as Wi Parata or Assets v Mere Roihi. Historic quasiconstitutional texts such as the Fenton Agreement are not on anyone's radar. There is not even an authoritative published collection of these various texts, which contemporary historians have had to resuscitate from the archives. Agreements of the present day can hardly be said to be not on the radar: they are certainly a matter of anxious concern to those involved. However, they are not a significant focus of academic commentary; this probably being explained by the opaque nature of the process and the inability of the Courts to discover a conceptual language by which it could become susceptible to legal scrutiny.

One advantage of rethinking the significance and status of post-Treaty Crown-Māori agreements is that it recognises the "bi-directionality" of government and indigenous relationships stressed by Professor Levaggi in the case of Argentina, which is no less true of New Zealand. Bringing such agreements to the fore might help to create a new kind of legal history that is more sensitive to the actual relationships between the Crown and Māori at any given time than a narrative based on

102 Pouwhare and Pryor v Attorney-General, Minister in Charge of Treaty Negotiations and Te Runanga o Ngati Awa (20 August 2002) HC WN CP 78/02 [Pouwhare]. Goddard J's decision was unsuccessfully appealed by some of the parties to the Court of Appeal. 
common law doctrine or on the consequences of statute. Historians of indigenous encounters are moving away from a simple oppositional model stressing resistance and conflicts to one paying closer attention to accommodation and continued indigenous agency. ${ }^{103}$ As Richard White, writing of the history of the interaction between governments and indigenous communities in the Great Lakes region of North America, has noted: ${ }^{104}$

The history of Indian-white relations has not usually produced complex stories. Indians are the rock, European peoples are the sea, and history seems a constant storm. There have been but two outcomes: The sea wears down and dissolves the rock; or the sea erodes the rock but cannot finally absorb its battered remnant, which endures. The first outcome produces stories of conquest and assimilation; the second produces stories of cultural persistence. The tellers of such stories do not lie. Some Indian groups did disappear; others did persist. But the tellers of such stories miss a larger process and a larger truth.

The meeting of sea and continent, like the meeting of whites and Indians, creates as well as destroys.

Contact was not a battle of primal forces in which only one could survive. Something new could appear.

Given these shifts in perception, it may be time for legal history to follow suit, and indeed to make its own contribution to seeing Crown and indigenous relationships in a new way. Whatever its shortcomings, and regardless of later events, texts such as the Fenton Agreement demonstrate that the Crown and a particular Māori group attempted to forge a relationship based not on any assumptions of the common law, but rather on the basis of an understanding worked out in New Zealand itself, and based on New Zealand political and constitutional realities. What is more, this is

103 This article is not the place to review the changing historiography of encounters between Europeans and indigenous peoples. Particularly noteworthy, however, is the work of James Lockhart and his colleagues, who focus on accommodation and adaptation in Mesoamerica and use as their primary sources "mundane" documents (wills, land titles, documents used in civil proceedings in the colonial courts) written in indigenous languages. The three key texts are James Lockhart The Nahuas After the Conquest: A Social and Cultural History of the Indians of Central Mexico, Sixteenth through Eighteenth Centuries (Stanford University Press, Stanford, 1992); Matthew Restall The Maya World: Yucatec Culture and Society 15501850 (Stanford University Press, Stanford, 1997); and Kevin Terraciano The Mixtecs of Colonial Oaxaca: Nudzahui History: Sixteenth through Eighteenth Centuries (Stanford University Press, Stanford, 2001). See also Lockhart's intellectual autobiography, "A Historian and the Disciplines" in Lockhart (ed) Of Things of the Indies (Stanford University Press, Stanford, California, 1999) 333-372. As an example of this approach, Terraciano's massively detailed account reconstructs the history of the colonial Mixtecs by relying on archival material, and particularly on material in the indigenous language, rather on the staple fare of colonial chronicles writing in Spanish. While Terraciano has little to say about the Spanish conquest of the region or its ecclesiastical history, the philological and textual emphases of the Lockhart school are exemplified by lengthy chapters on writing and language during the colonial period. Other chapters of the book deal with such issues as "communities", "social relations", "sacred relations" and "ethnicity". No-one has tried to write a history of $19^{\text {th }}$ century Māori in the same way, but it would be perfectly possible for a scholar of the right historiographical and linguistic abilities to do so, given that the amount of documentation in Māori is far more substantial than that available in the Nudzahui language of the Mixtecs.

104 Richard White The Middle Ground: Indians, Empires and Republics in the Great Lakes Region (Cambridge University Press, Cambridge, 1991) ix. 
a process which has endured and which has revitalised. At the same time, it has to be said that the Crown's record in terms of compliance with post-Treaty of Waitangi agreements has not always been what it should be - as the government has from time to time been prepared to acknowledge or that Māori are necessarily happy with the current negotiations and settlement programme. The growing number of Waitangi Tribunal urgent inquiries into the latter is a clear indication of dissatisfaction with at least some aspects of the process. ${ }^{105}$

As to whether or not the post-Treaty of Waitangi agreements are "treaties", the initial question posed at the start of this article, there can be no clear answer. In the United States, the Fenton Agreement would be regarded as a treaty, and for that matter so would many, and indeed perhaps all, of the pre-emptive purchase deeds. In New Zealand, the tendency has not been exactly one of denying that Crown-Māori agreements are "treaties", as one of relying very characteristically on Parliamentary sovereignty as a means of converting the text into legal effect and sidestepping the question. Whether we choose to call the Fenton Agreement a "treaty" becomes largely a question of the meaning of words, the most futile and useless variety of intellectual debates. In writing an article such as this, one can sometimes only develop a clear sense of what one is trying to demonstrate by writing it and by seeing where things seem to lead to. The position, after much inconclusive pondering on my part, seems to be this: an important, indeed a vital dimension of the Crown-Māori relationship since the Treaty of Waitangi has been the written agreement. (Maybe, an idea that occurs to me at the end of this exercise, it was the Treaty of Waitangi itself which was the precedent for the process I have tried to describe, a thought to perhaps be developed elsewhere.) These agreements are very plentiful. Moreover, this characteristic of our polity is an enduring one. It is more important than ever. The agreements are political, and on the whole the courts have not concerned themselves with them. In that sense, between the decisions in Wi Parata and Pouwhare there is a kind of continuity (although not in any other sense, I feel I must hasten to add). Vincent O'Malley has written that historians of the colonial period need to question "the terminology we have hitherto employed to describe many of the early arrangements entered into between Māori and the Crown". ${ }^{106}$ My principal conclusion is that lawyers and legal historians alike need to train their focus onto these agreements rather more than they have. ${ }^{107}$

105 See the Waitangi Tribunal's Pakakohi and Tangahoe Settlement Claims Report: Wai 758 (Legislation Direct, Wellington, 2000); The Ngāti Awa Settlement Cross-Claims Report: Wai 958 (Legislation Direct, Wellington, 2002); The Ngāti Tüwharetoa ki Kawreau Settlement Cross-Claim Report: Wai 996 (Legislation Direct, Wellington, 2003); The Te Arawa Mandate Report: Wai 1150 (Legislation Direct, Wellington, 2004); and The Te Arawa Mandate Report: Te Wahanga Tuarua: Wai 1150 (Legislation Direct, Wellington, 2005).

106 "Treaty-making", above n 6, 144.

107 Of course one must not, on the other hand, over-emphasise the existence of Crown-Māori agreements to the extent of downplaying the vital significance of the engagement between Māori and the common law - on which see especially the relevant chapters of McHugh Aboriginal Societies, above n 95. 
One concern that must be squarely faced is that any attempt to reconsider the status and effect of other agreements might lead to a diminution of the status of the Treaty of Waitangi. It is not my intention to do anything of the kind. The Treaty of Waitangi must always retain its unique, if complex, place. It came first, and must always be more than a primus inter partes. For as long as New Zealand exists as a sovereign political entity, the Treaty of Waitangi will remain central to national identity. But the centrality of the Treaty of Waitangi does not have to mean that other agreements and texts must be written out of legal history and constitutional discourse. It is not obvious that the Treaty of Waitangi precludes the Urewera agreement of 1895, for instance, as having a public law status of some kind, or that is should be written out of the country's constitutional and legal history.

It may be said that to give enhanced prominence to other agreements is to unnecessarily confuse things - the present day implications and consequences of the Treaty of Waitangi being complicated enough. The nation needs a dispirin, not further headaches. But, as this article has (I hope) shown, the legal and constitutional history of New Zealand is complicated, and much more interesting than is often supposed. The apparent simplicity of the New Zealand constitution in fact masks a much more complex and ambiguous reality. That the Crown would conduct high-level negotiations between a delegation of chiefs from a de facto independent zone, incorporate the agreement into a written text, and then translate that text into law as late as 1896, must reveal something of real significance about the true history of the intricate polity we all live in. Equally worthy of attention is that the Crown continues to negotiate with Māori, and continues to draw up written agreements and enact them into law. Aotearoa-New Zealand is indeed an interesting place. 